\title{
BIOLOGICAL CHEMISTRY
}

\section{Gsm}

\section{EDITOR-IN-CHIEF}

Bernhard Brüne 


\section{BIOLOGICAL CHEMISTRY}

Founded in 1877 by Felix Hoppe-Seyler as Zeitschrift für Physiologische Chemie

Felix Hoppe-Seyler (1825-1895) was a pioneer of biochemistry, remembered not only for his discovery of hemoglobin and his contributions to the chemical characterization of many other biological compounds and processes but also for having been the mentor of Friedrich Miescher and Albrecht Kossel. In his preface to the first issue of Zeitschrift für Physiologische Chemie, Felix Hoppe-Seyler coined the term Biochemistry ('Biochemie') for the then newly emerging discipline.
EDITOR-IN-CHIEF

B. Brüne, Frankfurt/Main

\section{EXECUTIVE EDITORS}

J. Buchner, Munich

M. Lei, Shanghai

S. Ludwig, Münster

H. Sies, Düsseldorf

D. Thomas, Chicago

B. Turk, Ljubljana

A. Wittinghofer, Dortmund

EDITORIAL BOARD

P. Agostinis, Leuven

L. Banks, Trieste

A.G. Beck-Sickinger, Leipzig

L. Boscá, Madrid

E. Cadenas, Los Angeles

I. Dikic, Frankfurt/Main

W.-X. Ding, Kansas City

A. Driessen, Groningen

K. Gevaert, Ghent

C. Hammann, Bremen

F.U. Hartl, Martinsried

D. Häussinger, Düsseldorf

$J$. Hiscott, Rome

L.-O. Klotz, Jena

M. Lamkanfi, Ghent

V. Magdolen, Munich

G. Mugesh, Bangalore

M. Müschen, San Francisco

C.M. Overall, Vancouver

G. Pejler, Uppsala

N. Pfanner, Freiburg

R. Pike, Melbourne

J. Potempa, Krakow

K. Sandhoff, Bonn

J. Scheller, Düsseldorf

C. Sommerhoff, Munich

G. Tiegs, Hamburg

J.M. Valpuesta, Madrid

ASSOCIATE EDITORS (GBM STUDY GROUPS)

C. Blattner, Karlsruhe

K. Giehl, Giessen

R. Hell, Heidelberg

J. Herrmann, Kaiserslautern

S. Hiller, Basel

C. Hunte, Freiburg

S. Knauer, Essen

I. Koch, Frankfurt/Main

C. Seidel, Düsseldorf

C. Villmann, Würzburg

\section{DE GRUYTER}


ABSTRACTED/INDEXED IN Academic OneFile (Gale/Cengage Learning), ASFA1: Biological Sciences \& Living Resources, Biochemistry \& Biophysics Citation Index, Biological Abstracts, BIOSIS Previews, CAB Abstracts, Calcium and Calcified Tissue Abstracts, Chemical Abstracts and the CAS databases, CSA Illustrata - Natural Sciences, CSA Neurosciences Abstracts, Current Contents/Life Sciences, Elsevier BIOBASE/Current Awareness in Biological Sciences (CABS), EMBASE - the Excerpta Medica database, EMBiology, Index Medicus/MEDLINE, Journal Citation Reports/Science Edition, Reaction Citation Index, Reference Update, Science Citation Index, Science Citation Index Expanded (SciSearch), Scopus, SIIC Data Bases, Zoological Record.

The Journal is associated with the Gesellschaft für Biochemie und Molekularbiologie e.V.

The publisher, together with the authors and editors, has taken great pains to ensure that all information presented in this work (programs, applications, amounts, dosages, etc.) reflects the standard of knowledge at the time of publication. Despite careful manuscript preparation and proof correction, errors can nevertheless occur. Authors, editors and publisher disclaim all responsibility for any errors or omissions or liability for the results obtained from use of the information, or parts thereof, contained in this work.

The citation of registered names, trade names, trademarks, etc. in this work does not imply, even in the absence of a specific statement, that such names are exempt from laws and regulations protecting trademarks etc. and therefore free for general use.

ISSN 1431-6730 · e-ISSN 1437-4315 · CODEN BICHF3

All information regarding notes for contributors, subscriptions, Open access, back volumes and orders is available online at www.degruyter.com/bc.

RESPONSIBLE EDITOR(S) Professor Dr. Bernhard Brüne, Goethe-University Frankfurt, Faculty of Medicine, Biochemistry I, Theodor-Stern-Kai 7, D-60590 Frankfurt/Main, Germany, Tel.: +49-69-6301 7424, Email: B.Bruene@ biochem.uni-frankfurt.de

JOURNAL MANAGER Dr. Torsten Krüger, De Gruyter, Genthiner Straße 13, 10785 Berlin, Germany, Tel.: +49 (0)30 260 05-176, Fax: +49 (0)30 260 05-298, Email: biol.chem.editorial@ degruyter.com

RESPONSIBLE FOR ADVERTISEMENTS Claudia Neumann, De Gruyter, Genthiner Straße 13, 10785 Berlin, Germany. Tel.: +49 (0)30 260 05-226, Fax: +49 (0)30260 05-264, Email: anzeigen@ degruyter.com

(C) 2018 Walter de Gruyter GmbH, Berlin/Boston

TYPESETTING Compuscript Ltd., Shannon, Ireland

PRINTING Franz X. Stückle Druck und Verlag e.K., Ettenheim

\section{COVER ILLUSTRATION}

On the front cover, immunofluorescence analysis of COS-7 African green monkey kidney cells expressing the mouse Serpina1 paralog DOM-7 is depicted (red: DOM-7; blue: endoplasmic reticulum marker Grp78/BiP; green: eGFP). The murine Serpinal genes are the orthologues to human $\alpha 1$-antitrypsin (SERPINA1) and they are important targets for the creation of authentic mouse models recapitulating human severe $\alpha 1$-antitrypsin deficiency. The mouse Serpinal cluster consists of three to five genes which are arranged on a $\sim 250 \mathrm{~kb}$ stretch on chromosome 12 and the number of paralogs as well as their exact arrangement is strain-dependent. So far, seven paralogs have been identified in different mouse strains (DOM-1 to -7) and it is known that DOM-1 and DOM-2 are efficient inhibitors of neutrophil elastase, whereas DOM-3, $-4,-5$ and -6 mostly inhibit chymotrypsin. So far, DOM-7 has not been functionally characterized. In their study presented on pp. 577-582 in this issue, Jülicher et al. isolated DOM-7 cDNA from BALB/cAnnCrl mice and confirmed the presence of a DOM-7-specific sequence in the BALB/c genome. DOM-7 was then overexpressed in COS-7 cells, and cell supernatants were used for functional analyses. In specialized assays DOM-7 inhibited both, neutrophil elastase and chymotrypsin. These results suggest that DOM-7 needs to be considered when aiming at the generation of authentic $\alpha 1$-antitrypsin deficiency models from DOM-7-positive mouse strains. Moreover, the complexity of the mouse Serpina1 gene locus may be larger than previously anticipated, and therefore needs to be properly analyzed before and after genome engineering by state-of-the-art methods, such as CRISPR.

Image courtesy of Reto Eggenschwiler, Hannover Medical School, Hannover, Germany.

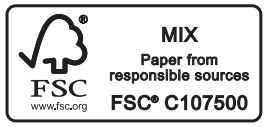




\section{Contents}

\section{Reviews}

Hans G. Drexler, Claudia Pommerenke, Sonja Eberth and Stefan Nagel

Hodgkin lymphoma cell lines: to separate the wheat from the chaff -511

\section{Saife Niaz}

The AGO proteins: an overview $-\mathbf{5 2 5}$

\section{Research Articles/Short Communications}

\section{Protein Structure and Function}

Sinem Milanos, Katharina Kuenzel, Daniel F. Gilbert, Dieter Janzen, Manju Sasi, Andrea Buettner, Thomas M. Frimurer and Carmen Villmann Structural changes at the myrtenol backbone reverse its positive allosteric potential into inhibitory $\mathrm{GABA}_{\mathrm{A}}$ receptor modulation $-\mathbf{5 4 9}$

Brian Lu, Miguel Munoz-Gomez and Yasuhiro Ikeda The two major glucokinase isoforms show conserved functionality in $\beta$-cells despite different subcellular distribution -565

Karen Jülicher, Annabell Wähner, Kerstin Haase, Karen W. Barbour, Franklin G. Berger, Lutz Wiehlmann, Colin Davenport, Karin Schuster-Gossler, Jörn Stitz, Tobias Cantz and Reto Eggenschwiler Functional characterization of the mouse Serpina1 paralog DOM-7 — 577

\section{Cell Biology and Signaling}

Kelei Li, Zhe Cong, Zhuoying Peng, Ting Chen, Jing Xue and Qiang Wei

CD45RO regulates the HIV-1 gp120-mediated apoptosis of $\mathrm{T}$ cells by activating Lck -583

Hongchao He, Jun Dai, Xiaoqun Yang, Xiaojing Wang, Fukang Sun and Yu Zhu

Silencing of MED27 inhibits adrenal cortical carcinogenesis by targeting the Wnt/ $\beta$-catenin signaling pathway and the epithelial-mesenchymal transition process -593

Libin Zhang, Liang Bu, Jiang Hu, Zheyuan Xu, Libo Ruan, Yan Fang and Ping Wang HDAC1 knockdown inhibits invasion and induces apoptosis in non-small cell lung cancer cells -603

Xuhua Xie, Xiaopei Xu, Changyu Sun and Zujiang Yu Hepatitis $B$ virus $X$ protein promotes proliferation of hepatocellular carcinoma cells by upregulating miR-181b by targeting ING5 - 611 